\title{
Monocular nystagmus in a patient with alternating hemiplegia of childhood
}

Javiera Tello, MD, Isadora Ruiz, MD, Luisa Herrera, PhD, Ana Miranda, MT, Paulina Alid, MD, and Mónica Troncoso, MD

Neurology ${ }^{\circledR}$ 2019;93:361. doi:10.1212/WNL.0000000000007977

Monocular nystagmus is a rare condition that occurs in limited number of disorders, such as spasmus nutans, multiple sclerosis, and alternating hemiplegia of childhood (AHC). ${ }^{1} \mathrm{AHC}$ is a neurodevelopmental disorder characterized by intermittent hemiplegic episodes with variable neurologic features. ${ }^{2}$

We present a 1-year-old infant with episodes of alternating hemiplegia and tetraplegia. He had onset at 7 months of life with monocular nystagmus (video). Neurologic examination was also notable for choreic and dystonic movements. Genetic sequencing confirmed mutation 2443G >A (p.Glu815Lys) in the ATP1A3 gene. Treatment with flunarizine has led to improvement with decreasing frequency and duration of episodes.

\section{Author contributions}

J. Tello: drafting and critical revision of manuscript. I. Ruiz: acquisition of data. L. Herrera: analysis and interpretation of data, critical revision of manuscript. A. Miranda: analysis and interpretation of data (molecular analysis). P. Alid: acquisition of data. M. Troncoso: critical revision of manuscript.

\section{Study funding}

No targeted funding reported.

\section{Disclosure}

The authors report no disclosures relevant to the manuscript. Go to Neurology.org/ $\mathrm{N}$ for full disclosures.

\section{Publication history}

Received by Neurology January 28, 2019. Accepted in final form May 20, 2019.

\section{References}

1. Kangsagra S, Mikati MA, Vigevano F. Alternating hemiplegia of childhood. Handb Clin Neurol 2013;112:821-826.

2. Masoud M, Prange L, Wuchich J, Hunanyan A, Mikati MA. Diagnosis and treatment of alternating hemiplegia of childhood. Curr Treat Options Neurol 2017;19:8.

\author{
Correspondence \\ Dr. Tello \\ javieratello@ug.uchile.cl
}

MORE ONLINE

- Video

From Pediatric Neurology (J.T., I.R., M.T.), the Hospital Clínico San Borja Arriarán, Central Campus Universidad de Chile; Human Genetics Program (L.H., A.M.), ICBM, Facultad de Medicina, Universidad de Chile, Santiago; and Hospital Regional de Talca (P.A.), Universidad Católica del Maule, Pediatric Neurology, Talca, Chile.

Go to Neurology.org/N for full disclosures. 


\section{Neurology}

\section{Monocular nystagmus in a patient with alternating hemiplegia of childhood \\ Javiera Tello, Isadora Ruiz, Luisa Herrera, et al. \\ Neurology 2019;93;361 \\ DOI 10.1212/WNL.0000000000007977}

\section{This information is current as of August 19, 2019}

\section{Updated Information \& Services}

References

Subspecialty Collections

Permissions \& Licensing

Reprints including high resolution figures, can be found at: http://n.neurology.org/content/93/8/361.full

This article cites 2 articles, 0 of which you can access for free at: http://n.neurology.org/content/93/8/361.full\#ref-list-1

This article, along with others on similar topics, appears in the following collection(s):

Developmental disorders

http://n.neurology.org/cgi/collection/developmental_disorders Nystagmus

http://n.neurology.org/cgi/collection/nystagmus

Information about reproducing this article in parts (figures,tables) or in its entirety can be found online at:

http://www.neurology.org/about/about_the_journal\#permissions

Information about ordering reprints can be found online:

http://n.neurology.org/subscribers/advertise

Neurology ${ }^{\circledR}$ is the official journal of the American Academy of Neurology. Published continuously since 1951, it is now a weekly with 48 issues per year. Copyright (O 2019 American Academy of Neurology. All rights reserved. Print ISSN: 0028-3878. Online ISSN: 1526-632X.

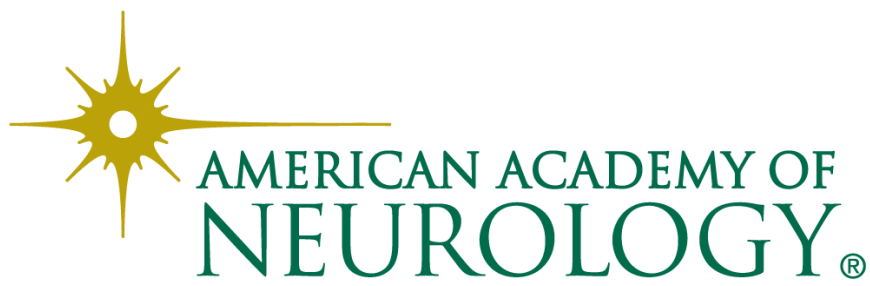

